\title{
A multi-parameter hydrochemical characterization of proglacial runoff, Cordillera Blanca, Peru
}

\author{
P. Burns ${ }^{1}$, B. Mark ${ }^{1}$, and J. McKenzie ${ }^{2}$ \\ ${ }^{1}$ Department of Geography, The Ohio State University, 1036 Derby Hall, \\ 154 North Oval Mall, Columbus, OH 43210-1361, USA \\ ${ }^{2}$ Earth and Planetary Science, McGill University, 3450 University Street, \\ Montreal, PQ H3A 2A7, Canada \\ Received: 23 December 2010 - Accepted: 6 September 2011 \\ - Published: 26 September 2011 \\ Correspondence to: B. Mark (mark.9@osu.edu) \\ Published by Copernicus Publications on behalf of the European Geosciences Union.
}

\begin{abstract}
The Cordillera Blanca, located in the central Peruvian Andes, is the most glacierized mountain range in the tropics. The study objective is to determine the spatial and topographic controls on geochemical and isotopic parameters in the Quilcayhuanca

5 drainage basin. During the dry season of July 2009, surface water and groundwater samples were collected from the proglacial zone of the $90 \mathrm{~km}^{2}$ Quilcayhuanca basin which is $20 \%$ glacierized. The basin water samples $(n=25)$ were analyzed for $\mathrm{pH}$, conductivity, major cations ( $\mathrm{Ca}, \mathrm{Mg}, \mathrm{Na}, \mathrm{K}, \mathrm{Fe}(\mathrm{II}))$, major anions $\left(\mathrm{F}, \mathrm{Cl}, \mathrm{SO}_{4}\right)$, nutrients (total $\mathrm{N}$, total $\mathrm{P}$, and $\mathrm{Si}$ ), and stable isotopes of water $\left(\delta^{18} \mathrm{O}, \delta^{2} \mathrm{H}\right)$. The valley's surface 10 water is acidic $\left(\mathrm{pH}_{3}-4\right)$ and is dominated by $\mathrm{Ca}^{2+}, \mathrm{Mg}^{2+}$, and $\mathrm{SO}_{4}^{2-}$, the last of which is likely due to pyrite oxidation. Total $\mathrm{P}$ and total $\mathrm{N}$ show no trend with elevation down valley, while Si generally increases with decreasing elevation. Groundwater samples are differentiated from surface water samples by lower $\mathrm{pH}$, specific conductance, and total $\mathrm{P}$ and higher $\mathrm{Na}^{+}, \mathrm{K}^{+}, \mathrm{HCO}_{3}^{-}, \mathrm{Si}$, and $\delta^{18} \mathrm{O}$. A two-component mixing model 15 indicates that discharge from the watershed is approximately two-thirds surface water (mostly glacier melt) and one-third groundwater. The results were compared to data from the Rio Santa and indicate that this trend may persist at the regional scale.
\end{abstract}

\section{Introduction}

Rapid glacier retreat in the tropical Andes is having significant consequences for mountain glaciers and the people who rely on glacially-fed water supplies (Bradley, 2006; Vuille et al., 2008). Among other effects, climate change and glacier recession threaten to decrease dry season discharge in this regions, representative of many global sites where highland water ecosystems reach downstream demand (Barnett et al., 2005; Weingartner et al., 2007). In the seasonally arid climate of the tropical Andes, glacier 25 meltwater buffers discharge throughout the year and provides a net increase in overall discharge (Mark et al., 2007) at the expense of the negative glacier mass balance. Therefore during the dry season or droughts, glacier meltwater is an important water 
resource. In addition to water resource quantity, water qualityis also an important issue. In this context, proglacial areas downstream from glaciers are significant as the fractional glacier melt contribution diminishes further downstream (i.e. Kaser et al., 2010). Thus we focus here on how glacier melt fed streams are impacted by water-rock chem5 istry throughout a proglacial valley.

The Cordillera Blanca, located in the central Andes of Peru, contains about $70 \%$ of the world's tropical glacier area (Vuille et al., 2008). Most of the Peruvian population lives along the Pacific coastal plains and western slopes of the Andes where the land is arid and heavily reliant on water runoff from the mountains (Vergara et al., 2007). Re-

10 cent global climate changes are locally manifest in the Cordillera Blanca as proglacial watersheds are undergoing hydrological transformations, affecting human vulnerability across multiple shifting vectors (Mark et al., 2010; Bury et al., 2010). Thus, understanding the current physical and chemical hydrology of the region is imperative for making future predictions about climate impacts.

15 The impact of melting glaciers on the hydrological cycle has been quantified on a regional scale, but more detailed, valley-specific analyses are required to characterize the geological controls and variability of water quality and stream discharge accurately (Mark et al., 2005). An understanding of these geological and hydrological controls is beneficial for the utilization of mixing models which can be used to determine relative 20 contributions from end-members such as precipitation, groundwater, and glacier melt. Previous work has successfully utilized major ion and isotope hydrochemistry over multiple years to identify end-member contributions from tributary streams to the Rio Santa (Mark et al., 2005; Mark and McKenzie, 2007). During the dry season, groundwater is one of the largest sources of water to the hydrologic system in the tributary valleys

25 (Baraer et al., 2009), yet many existing models oversimplify the role of groundwater in glacial environments (Hood et al., 2006). This case study focuses on the hydrochemistry of waters in a proglacial valley during the 2009 dry season, when precipitation is minimal and the relative contributions of glacier melt water and groundwater to streams is predominate (Mark and Seltzer, 2003). The proglacial zone is a mosaic of moraines

and other deposits related to glacier advance, retreat, and hydrology (Tranter, 2005). This area has the potential for high geochemical activity, because it contains a variety of comminuted glacial debris, is subject to reworking by glaciofluvial activity, and can be colonized by vegetation. Waters interacting with sediment in this area mainly acquire

5 new solutes via sulfide oxidation and carbonate dissolution (Anderson et al., 2000; Cooper et al., 2002). Furthermore, the concentration of solutes in the proglacial zone is normally higher than solute concentrations of glacial runoff (Tranter, 2005). Natural springs and low-gradient, low permeability plains called pampas are the main sources of groundwater in the proglacial zone of the Quilcayhuanca drainage basin.

10 A variety of hydrochemical parameters (ions, nutrients and stable isotopes) are examined to explore the fate of glacier meltwater downstream from receding glaciers in the Quilcayhuanca basin of the Cordillera Blanca, Peru. The primary objective of the paper is to understand how the geology and hydrology contribute to changes in the hydrochemistry and stable isotopes of surface water progressively downstream from

15 the glaciers. Hydrochemical and isotopic variation between groups of samples from similar locations (e.g. principal channel surface water, tributaries, and groundwater) can be used in simple mass-balance mixing models. A two end-member mixing model is used to determine relative contributions of groundwater to the Quilcayhuanca basin, and these results are then scaled to the large Cordillera Blanca drainage basin.

\section{Study area}

The Quilcayhuanca basin is part of the Cordillera Blanca, which spans over $120 \mathrm{~km}$ between $8.5-10^{\circ} \mathrm{S}$ latitude in the central Peruvian Andes (Fig. 1). The range strikes northwest-southeast and separates stream runoff between the Pacific and Atlantic oceans. Between 1970 and 2003 the surface area of glaciers in the Cordillera Blanca 25 decreased from 723 to $597 \mathrm{~km}^{2}$, a $22 \%$ loss (Racoviteanu et al., 2008). Future climate scenarios predict that these glaciers could disappear completely by 2200 (Pouyaud, 2004; Pouyaud et al., 2005). 
Water originating from the Quilcayhuanca basin drains into the Rio Santa near the city of Huaraz (population 120000). The Rio Santa drains the Cajellon de Huaylas watershed $\left(4900 \mathrm{~km}^{2}\right)$ which captures runoff from the western side of the Cordillera Blanca and eastern side of the non-glacierized Cordillera Negra. Originating at La5 guna Conococha, the Rio Santa travels over $300 \mathrm{~km}$ to the Pacific Coast, descending from $4300 \mathrm{~m}$ and draining a watershed of $12200 \mathrm{~km}^{2}$. The Rio Santa has the second largest discharge of rivers draining to the Pacific coast of Peru and also has the most regular monthly flow (Mark and Seltzer, 2003). Rio Santa discharge has a strong seasonal pattern, reflecting that approximately $80 \%$ of total annual precipitation falls from

10 roughly October to May (Mark et al., 2010). Contributions from glacier melt are thus most important during the dry season which is from roughly June to September.

The Quilcayhuanca basin has a drainage area of $90 \mathrm{~km}^{2}$ and is approximately $20 \%$ glacierized based on 2009 Advanced Spaceborne Thermal Emission and Reflectance Radiometer (ASTER) satellite imagery. In 2009 glaciers in the basin covered an area 15 of $18 \mathrm{~km}^{2}$. Glacier outlines, name, type (in some cases), and size are available from the Global Land Ice Measurements from Space (GLIMS) glacier database (Armstrong et al., 2005). The valley has a distinct "Y" shape (Fig. 2). In later discussions and tables the northern right-lateral branch is referred to as Quil-R while the southern left-lateral branch is referred to as Quil-L. The main section of the valley at and below where the 20 two upper branches merge is referred to as Quil-M.

Figure 2 is a geologic map of the Quilcayhuanca basin and Fig. 3 is a hillshade of a Light Detection and Ranging (LiDAR) digital elevation model (DEM), focused on the upper portion of the valley. The purple line on Fig. 3 represents the contact between two different geologic formations. In both Figs. 2 and 3 sampling locations are plotted with symbols appropriate to their grouping and their site number which are explained below. The valley geology is dominated by metasedimentary and intrusive igneous rocks. The Chicama formation ( $14 \%$ of basin area) dominates the upper portion of the valley. It contains metamorphic sedimentary rocks of Jurassic age, characterized by weathered shale, argillite, sandstone, and pyrite. Intrusive rocks ( $43 \%$ of basin area) dominate

the high, steep walls of the mid to lower-valley. This intrusive body is characterized as granodiorite and tonalite which is approximately $8.2 \pm 0.2$ million years old (McNulty et al., 1998). Quaternary moraines, glaciolacustrine deposits, glaciofluvial deposits, and pampas compose the remainder of the valley (15\% of basin area).

5 Pampas are defined as low-gradient areas that formed from paludified moraine dammed lakes. The pampas are composed mostly of low-permeability, organic-rich, unconsolidated material and buried, higher permeability colluvial deposits (Mark and McKenzie, 2007). Glacial deposits, fluvial deposits, and pampas are important geological components controlling hydrochemistry as they are low gradient systems compared

10 to the steep valley sides and thus they should theoretically contain water with longer residence times. Cuchillacocha Lake and Tuplacocha Lake, with areas of $0.14 \mathrm{~km}^{2}$ and $0.46 \mathrm{~km}^{2}$ respectively, are located immediately in front of glaciers in Quil-R. There are no major lakes in Quil-L.

\section{Methodology}

15 The study is based on the analysis of 25 water samples for major ion chemistry, nutrients, and the stable isotopes of water. Samples were divided into three hydrologic groups to look at spatial patterns, such as elevation: (1) Quil Streams, represented in figures by blue-filled circles, is the group of sampling sites $(n=14)$ from principal stream channels in each of the three valley sections (referred to as Quil-L, Quil-R, or

20 Quil-M in Tables); (2) Tributaries Group, represented by green-filled squares, is composed of tributary samples $(n=8)$ in each of the three sections of the valley (referred to as Tribs in Tables); and (3) Groundwater Group, represented by red-filled triangles, is composed of groundwater samples $(n=3)$ taken from springs (referred to as GW in Tables).

25 Tributaries were sampled in both upper sections of the basin. In Quil-R samples were taken from two tributaries (sites \#2 and \#3) thought to be draining a high elevation groundwater storage area called Jatun. In Quil-L samples were taken from tributaries on either side of the valley. In general, waters in the upper portion of the basin flow over 
bedrock, through moraines, and though fluvial deposits. Once the waters enter Quil-M they are mostly flowing across pampas. Waters draining from the Quilcayhuanca basin flow down a steeper gradient through the city of Huaraz. However, before the waters from Quilcayhuanca reach Huaraz, they merge with streams from two adjacent valleys.

5 The most downstream water sample, site Quilcay (\#25), was taken at a point just above the city of Huaraz, approximately $2 \mathrm{~km}$ before the stream enters the Rio Santa.

\subsection{Sample collection and analysis}

Water samples were collected in the Quilcayhuanca basin during a three day period of the dry season (15-17 July 2009). Samples for major ions $\left(\mathrm{Ca}^{2+}, \mathrm{Mg}^{2+}, \mathrm{Na}^{+}, \mathrm{K}^{+}, \mathrm{Fe}^{2+}\right.$, $10 \mathrm{Fe}^{3+}, \mathrm{F}^{-}, \mathrm{Cl}^{-}$, and $\mathrm{SO}_{4}^{2-}$ ), nutrients (total Phosphorus $(\mathrm{P})$, total Nitrogen $(\mathrm{N})$, and Silica $(\mathrm{Si}))$, and stable isotopes $\left(\delta^{18} \mathrm{O}, \delta^{2} \mathrm{H}\right)$ were filtered into new HDPE $60 \mathrm{ml}$ Nalgene bottles using a $60 \mathrm{ml}$ HDPE syringe and a $0.45 \mu \mathrm{m}$ pore-size Nucleopore screw-on filter. Water samples were subsequently stored in a dark, cool locations until analysis. During sample collection at almost all of the sites a YSI Multimeter Probe was used

15 for field measurements of temperature, $\mathrm{pH}$, and specific conductance. During 14-15 July, the site Quil Bel Conf, located approximately $100 \mathrm{~m}$ below the confluence of the streams draining Quil-L and Quil-R, was sampled every hour for $24 \mathrm{~h}$ to observe diurnal variations. Additional water samples $(n=11)$, but not field measurements, were taken along the Rio Santa and Cordillera Negra $(n=4)$ for comparison with Quilcayhuanca

20 samples. Table 1 lists each Quilcayhuanca site name and number, as well as each site's elevation, $\mathrm{pH}$, and specific conductance.

Anion concentrations were measured by ion chromatography at the Hydrogeology Laboratory, Department of Earth and Planetary Sciences, McGill University (Dionex DX-100 with Dionex AS14 column, guard and suppressor). Dissolved concentrations

25 of major cations were measured by atomic absorption spectrometry on a Perkin Elmer AAnalyst 100 at the Trace Element Analytical Laboratory (TEAL) at McGill University. Bicarbonate $\left(\mathrm{HCO}_{3}^{-}\right)$was calculated as the difference in the solution charge balance.

2489

Concentrations of nutrients (total P, total N, and Si) were measured using a Skalar $\mathrm{San}^{++}$Automated Wet Chemistry Analyzer in the School of Earth Sciences at The Ohio State University. Total P is a combination of orthophosphates, polyphosphates, and organic phosphorus. Total $\mathrm{N}$ includes organic nitrogen, ammonia, and nitrate plus 5 nitrite. Duplicate samples analyzed for total N, P and Si had average precisions of $11 \%, 3 \%$ and $1 \%$, respectively. Silica values were reported as ppb $\mathrm{Si}$ as $\mathrm{SiO}_{2}$.

Stable isotopes of water were measured at Byrd Polar Research Center at The Ohio State University using mass spectroscopy (Finnigan MAT Delta Plus coupled to a HDO water equilibrator). Stable isotopes are reported using the $\delta$-notation reported rela- tive to the Vienna-Standard Mean Ocean Water (VSMOW) standard, with accuracy of $\pm 0.1 \%$ or $\delta^{18} \mathrm{O}$ and $\pm 1 \%$ or $\delta^{2} \mathrm{H}$. Based on duplicates, $\delta^{18} \mathrm{O}$ measurements had a precision of $0.2 \%$ and $\delta^{2} \mathrm{H}$ measurements had a precision of $2.4 \%$.

A t-test was used to determine if sample groups (Quil Streams, Tributaries, and Groundwater) were statistically different from one another in terms of the various hy15 drochemical components being examined in this study. For this study a probability below the $5 \%$ significance level $(p<0.05)$ refutes the null hypothesis that there is no difference between the two groups and confirms the alternative hypothesis that the two groups are different from one another.

\subsection{Mixing model}

20 A two component chemical mixing model was used to estimate relative contributions of surface water and groundwater at two sites in Quilcayhuanca valley. The first site, Quil Bel Conf (\#19), was chosen because it sits above the pampa of the lower valley which is hypothesized to be a potential storage site for groundwater. The second site, Park Entrance (\#24), is located at the lower end of the pampa (Fig. 2). Thus the

25 relative percentages of groundwater and surface water at this site should represent the net mixture of groundwater and surface water exiting the valley as surface water. Averaged values of different parameters for the groups Quil Streams and Groundwater were used as the two end-members. The group Quil Streams is the union of the three 
subgroups Quil-L, Quil-R, and Quil-M. Precipitation was not used as an end member because precipitation events are rare, short duration events during the dry season and no precipitation samples were collected from Quilcayhuanca (Mark et al., 2005).

Similar to Baraer et al. (2009) selected tracers had to be conservative, meaning 5 that values measured in the mixed stream water had to be within the range of source concentrations. Average values for each source were calculated from sites above the mixing point. The tracers that met these selection criteria were $\mathrm{Ca}^{2+}, \mathrm{Mg}^{2+}, \mathrm{SO}_{4}^{2-}, \mathrm{Si}$, and $\delta^{18} \mathrm{O}$. The mixing equation is:

$C_{\text {out }}=f_{1} C_{\mathrm{Qms}}+\left(1-f_{1}\right) C_{\mathrm{GW}}$

10 where $f_{1}$ is the unknown fraction of water at the site coming from surface water, (1$f_{1}$ ) is the unknown fraction of water at the site coming from groundwater, $C_{\text {out }}$ is the average measured concentration of components at the site in question, $C_{\mathrm{Qms}}$ is the average measured concentration of components for the group Quil Streams, and $C_{\mathrm{GW}}$ is the average measured concentration of components for the group Groundwater.

\section{Results and discussion}

\subsection{Field measurements}

Discharge of the principal valley streams increases progressively down-valley. The discharge from the Cuchillacocha Lake outflow (\#1) in Quil-R was measured to be $0.1 \mathrm{~m}^{3} \mathrm{~s}^{-1}$, while the highest sampling site in Quil-L, Cayesh Hi (\#7), had a discharge

20 of about $0.2 \mathrm{~m}^{3} \mathrm{~s}^{-1}$. The discharge was measured to be $0.8 \mathrm{~m}^{3} \mathrm{~s}^{-1}$ at the confluence (\#19) of Quil-L and Quil-R. Near the end of the valley at the site Park Entrance (\#24) the discharge was measured to be $1.2 \mathrm{~m}^{3} \mathrm{~s}^{-1}$.

The average $\mathrm{pH}$ for all sites in Quilcayhuanca was 3.6 and the overall range of $\mathrm{pH}$ measurements was from 2.8 to 7.3 (Table 1). This range shows a stark contrast compared to the normal $\mathrm{pH}$ range of $7-10$ seen in most glacial environments (Tranter, 2491

2005). During the $24 \mathrm{~h}$ sampling period the $\mathrm{pH}$ at the site Quil Bel Conf (\#19) varied between 3.3 and 3.7. Quil Streams $(n=14)$, the combination of Quil-L, Quil-R, and Quil-M, had an average $\mathrm{pH}$ of 3.8 and ranged from $\mathrm{pH}$ 3.4-5.4. Groundwater samples $(n=3)$ taken from springs averaged $\mathrm{pH} 6.4$ and ranged from $\mathrm{pH} 6.1-7.3$. Tributary 5 samples $(n=8)$ had an average $\mathrm{pH}$ of 3.4 and ranged from $\mathrm{pH}$ 2.8-7.1.

Overall the $\mathrm{pH}$ of Quil Streams increases with decreasing elevation. This trend is attributed to the increasing net contribution of groundwater down-valley. Furthermore, Quil Streams sites in the Quil-M section of the valley should have a higher $\mathrm{pH}$ relative to main channel sites in Quil-L and Quil-R because tributaries feeding the principal 10 channel are not exposed to the pyrite $\left(\mathrm{Fe}_{2} \mathrm{~S}\right)$ bearing Chicama formation, which is the main driving force for production of $\mathrm{H}^{+}$ions in the valley. Groundwater sites can be thought of as a separate grouping since samples have statistically different (t-test: $p<0.0001) \mathrm{pH}$ compared to Quil Streams. The groundwater sites do not show a trend with elevation. The $\mathrm{pH}$ of tributary streams also do not show a trend with elevation and 15 have a much greater range than Quil Streams and groundwater.

The overall average specific conductance, a measure of total ionic activity in water, for all sites was $251 \mu \mathrm{S} \mathrm{cm}^{-1}$ although a large range was observed $\left(26-495 \mu \mathrm{S} \mathrm{cm}^{-1}\right)$. Quil Streams $(n=14)$ had an average specific conductance of $318 \mu \mathrm{Scm}^{-1}$ and ranged from $226-495 \mu \mathrm{S} \mathrm{cm}^{-1}$. Tributaries had an average specific conductance of $20206 \mu \mathrm{S} \mathrm{cm}^{-1}$ and a large range $\left(53-421 \mu \mathrm{S} \mathrm{cm}^{-1}\right)$. Groundwater sites $(n=3)$ had an average specific conductance of $77 \mu \mathrm{S} \mathrm{cm}^{-1}$ and ranged from $26-116 \mu \mathrm{S} \mathrm{cm}^{-1}$. Specific conductance of Quil Streams is statistically different (t-test: $p<0.0006)$ from groundwater possibly due to the fact that igneous and metamorphic rocks contain silicates and alumino-silicate minerals that are slow to react with groundwater that has a nearly 25 neutral $\mathrm{pH}$.

The specific conductance values from all groups were plotted versus elevation (Fig. 4a). The solid blue significant trend line fit only through Quil Streams, but excluding the outlier site Quilcay (\#25), shows that specific conductance decreases with decreasing elevation. This trend can be interpreted based on stream discharge. In 
glacial environments, as discharge increases, specific conductance decreases (Anderson et al., 2003; Tranter, 2005) because glacier meltwater is usually more dilute than surface water in the proglacial zone. Another interpretation is that surface waters are interacting and mixing more with groundwater in the pampas of Quil-M, which coincides

5 with the $\mathrm{pH}$ decrease down valley due to increasing contributions from groundwater in the lower portions of the valley. It is also noteworthy that the tributaries Jatun Upper Conf (\#2), Jatun Mid (\#3), and North Waterfall (\#21) are all similar to groundwater in terms of $\mathrm{pH}$ and specific conductivity (circled on Fig. 4a). This suggests that either the waters are originating from a groundwater source in the upper portion of Quil-R or

10 they are interacting with a different lithology, presumably the intrusive formation which should not yield acidic waters.

During the $24 \mathrm{~h}$ sampling period the values for specific conductance at the site Quil Bel Conf ranged from $349-466 \mu \mathrm{S} \mathrm{cm}^{-1}$ (Fig. 5). From the local time of the first sample (09:30 p.m.), the specific conductance gradually decreased to its low value at 15 07:30 a.m. After 07:30 a.m. the specific conductance gradually increased to its high value at 14:30 (02:30 p.m.) and then gradually decreased again. With knowledge of the specific conductance variation between surface water and groundwater in the valley one explanation for this diurnal variation might be that surface water, originating mostly from glacier melt, contributes a greater percentage during the warmer daylight hours 20 while groundwater has an increased role during the night ( 07:00 p.m.-07:00 a.m.). Anderson et al. (2003) showed that discharge of a river in a glacial valley (Kennicott River, Alaska) is inversely proportional to electrical conductivity. However, those measurements were made much closer to the glacier terminus $(0.5 \mathrm{~km})$ and in alkaline waters. The sampling site in this study should have a greater solute concentration because streams draining to this site have a much lower $\mathrm{pH}$, presumably favoring mineral dissolution, and a greater distance ( $\sim \mathrm{km}$ from the terminus) to interact with minerals in the proglacial zone.

\section{2 lons}

The relative average composition of all samples taken in Quilcayhuanca valley was calculated and the abundances of the cations relative to the total sum of cations is $\mathrm{Ca}^{2+}$ $(48 \%), \mathrm{Mg}^{2+}(30 \%), \mathrm{H}^{+}(12 \%), \mathrm{Fe}^{2+}(6 \%), \mathrm{Na}^{+}(4 \%), \mathrm{K}^{+}(1 \%)$, similar to normal rel5 ative abundances in fresh water systems (Hounslow, 1995). The abundances of the anions relative to sum of anions are $\mathrm{SO}_{4}^{2-}(98 \%), \mathrm{HCO}_{3}^{-}(1 \%), \mathrm{Cl}^{-}(0.5 \%), \mathrm{F}^{-}(0.5 \%)$. The high sulfate concentrations are unusual in most natural settings, but can be explained by sulfide oxidation reactions (Hounslow, 1995). Average ionic compositions were also computed for each of the major groupings, Quil Streams, Tributaries, and 10 Groundwater and are compared to the Rio Santa (Tables 2 and 3).

Glacial runoff is usually a dilute $\mathrm{Ca}^{2+}-\mathrm{HCO}_{3}^{-}-\mathrm{SO}_{4}^{2-}$ solution with variable $\mathrm{Na}^{+}-\mathrm{Cl}^{-}$ (Tranter, 2005) and is usually more dilute than global mean river water (Anderson et al., 1997). Compared to average chemical compositions of some of the major rivers of the world (Faure, 1998), $\mathrm{Ca}^{2+}$ and $\mathrm{Mg}^{2+}$ concentrations from this study are above global 15 averages while the other major ions $\left(\mathrm{Na}^{+}, \mathrm{K}^{+}, \mathrm{Cl}^{-}\right.$, and $\left.\mathrm{HCO}_{3}^{-}\right)$are below these global river averages. Furthermore, ionic concentrations from this study can be compared with concentrations of major ions in glacial runoff from different regions of the world (Brown, 2002). Concentrations of all the major ions, except $\mathrm{Mg}^{2+}$ and $\mathrm{SO}_{4}^{2-}$, are similar when compared with ranges from other glacial environments while $\mathrm{Mg}^{2+}$ and $\mathrm{SO}_{4}^{2-}$

20 are anomalously high in comparison. Unusually high $\mathrm{Mg}^{2+}$ concentrations may be the result of weathering of common minerals found in granodiorite and tonalite, such as amphibole, biotite, and possibly pyroxene. Very high $\mathrm{SO}_{4}^{2-}$ concentrations are the result of pyrite oxidation in the shales of the metasedimentary Chicama formation in the upper section of the valley.

Pyrite oxidation, described by the equation below (Faure, 1998; Fortner et al., 2011), is likely the driving force of this unusually acidic natural system.

$\mathrm{FeS}_{2}+\frac{7}{2} \mathrm{H}_{2} \mathrm{O}+\frac{15}{4} \mathrm{O}_{2} \rightarrow \mathrm{Fe}(\mathrm{OH})_{3}+2 \mathrm{SO}_{4}^{2-}+4 \mathrm{H}^{+}$ 
The oxidation of pyrite can also take place in the absence of $\mathrm{O}_{2}$ with $\mathrm{Fe}^{3+}$ serving as an electron acceptor:

$\mathrm{FeS}_{2}+14 \mathrm{Fe}^{3+}+8 \mathrm{H}_{2} \mathrm{O} \rightarrow 15 \mathrm{Fe}^{2+}+2 \mathrm{SO}_{4}^{2-}+16 \mathrm{H}^{+}$

Utilizing hydrolysis, sulfide oxidation is a dominant reaction in subglacial and proglacial 5 environments. These reactions provide protons to solution, lowering the $\mathrm{pH}$ and allowing for more carbonate dissolution. The oxidation of pyrite preferentially dissolves carbonates, rather than silicates, because of a faster reaction rate (Tranter, 2005) and the processes can be accelerated by bacterial activity (Faure, 1998).

In natural settings, pyrite oxidation usually occurs in debris-rich environments where

10 bedrock is crushed and scoured from past glacial contact (Tranter, 2005). Accordingly in this study, the Chicama formation in the upper valley (Fig. 3 with Chicama $\mathrm{fm}$. contact) is exposed and steeply sloped debris piles abound, notably next to the two lakes and in Quil-L. Thus in the two lakes and Quil-L scoured rocks from the Chicama formation likely cause talus deposits that intersect with already acidic waters, further 15 continuing the oxidation of pyrite and addition of protons to the surface waters.

Samples can also be compared by group. For example, there is little variation between Quil Streams and the Tributaries group. However, there are major differences between these two groups and Groundwater. Groundwater samples were, on average, lower in relative percentages of $\mathrm{Mg}^{2+}, \mathrm{H}^{+}$, and $\mathrm{SO}_{4}^{2-}$ and higher in relative percentages

20 of $\mathrm{Na}^{+}, \mathrm{K}^{+}$, and $\mathrm{HCO}_{3}^{-}$. Increased percentages of $\mathrm{Na}^{+}$and $\mathrm{K}^{+}$in groundwater could be explained by cation exchange processes (Hounslow, 1995) while increased percentages of $\mathrm{HCO}_{3}^{-}$could be explained by increased interactions with trace carbonates along groundwater flow paths or decreased interaction with pyrite and other sulfide minerals which lower the $\mathrm{pH}$ and reduce alkalinity.

\section{$25 \quad 4.3$ Nutrients}

Three nutrients, total $\mathrm{P}$, total $\mathrm{N}$, and $\mathrm{Si}$, were considered (Table 4). The average total $\mathrm{P}$ for all samples from Quilcayhuanca was $971 \mathrm{ppb} \mathrm{P}$ as $\mathrm{PO}_{4}^{3-}$ with values ranging from 2495

0-2197 ppb $\mathrm{P}$ as $\mathrm{PO}_{4}^{3-}$. Quil Streams had an average value of $1211 \mathrm{ppb} \mathrm{P}$ as $\mathrm{PO}_{4}^{3-}$ with a range of $687-1376 \mathrm{ppb} \mathrm{P}$ as $\mathrm{PO}_{4}^{3-}$. Tributaries in the valley had an average value of $738 \mathrm{ppb} \mathrm{P}$ as $\mathrm{PO}_{4}^{3-}$ and a range of $0-2197 \mathrm{ppb} \mathrm{P}$ as $\mathrm{PO}_{4}^{3-}$. However the tributary average is somewhat unrepresentative as four of the samples had values close to or 5 equal to zero, while the other 4 samples had values greater than $1000 \mathrm{ppb} \mathrm{P}$ as $\mathrm{PO}_{4}^{3-}$.

Groundwater sites had an average value of $443 \mathrm{ppb} \mathrm{P}$ as $\mathrm{PO}_{4}^{3-}$ and ranged from 9 $1297 \mathrm{ppb} \mathrm{P}$ as $\mathrm{PO}_{4}^{3-}$. The two springs in the upper portion of the valley had values close to zero while the site Quil Spring (\#23) had the maximum value for the group. Total $P$ shows no trend with elevation (Fig. 4b), and all groundwater sites (with the exception 10 of Quil Spring and sites possibly originating from groundwater such as Jatun Upper Conf (\#2), Jatun Mid (\#3), and North Waterfall (\#21)) have very low total $P$ values. This observation suggests that total P could be used to distinguish between Groundwater and Quil Streams which are statistically different (t-test: $p<0.003$ ).

Rocks which are comminuted by intense physical erosion release phosphorus. Av15 erage crustal rocks contain $1050 \mathrm{ppm}$ of phosphorus, primarily from sparingly soluble minerals such as apatite and from calcium, aluminum, and ferrous phosphates (O'Neil, 1985). In glacial environments, between $1-23 \mu \mathrm{g} \mathrm{P} \mathrm{g}^{-1}$ is present as readily extractable phosphorus on the surfaces of glacial flour (Hodson et al., 2004) and P fluxes from glacial environments are likely to respond directly to increased meltwater runoff (Hod-

20 son, 2009). In this study total $P$ showed no trend with elevation (Fig. 4b), contrary to an expected trend of decreasing phosphorus with elevation. Scoured phosphate minerals should be most readily available near the glacier termini and thus measured total $\mathrm{P}$ concentrations should have their highest values at the highest sampling elevations. Additionally in older sediments of the lower valley, more of these scoured minerals should have been removed compared to the most recently glacierized terrain in the upper valley as plants in the lower valley should utilize $P$ and remove it from aquatic systems. 
The average total $\mathrm{N}$ for all samples from Quilcayhuanca was $391 \mathrm{ppb} \mathrm{N}$ as $\mathrm{NO}_{3}^{-}$with a range of $161-1957 \mathrm{ppbN}$ as $\mathrm{NO}_{3}^{-}$. Quil Streams averaged $381 \mathrm{ppbN}$ as $\mathrm{NO}_{3}^{-}$and had a range of $161-708 \mathrm{ppbN}$ as $\mathrm{NO}_{3}^{-}$. Tributaries had an average of $258 \mathrm{ppbN}$ as $\mathrm{NO}_{3}^{-}$and a relatively narrow range of $201-336 \mathrm{ppb} \mathrm{N}$ as $\mathrm{NO}_{3}^{-}$. Groundwater samples

5 had an average of $836 \mathrm{ppb} \mathrm{N}$ as $\mathrm{NO}_{3}^{-}$and a range of $205-1957 \mathrm{ppb} \mathrm{N}$ as $\mathrm{NO}_{3}^{-}$. Two of the groundwater measurements are similar, but the third measurement, J Spring (\#12), is very high and results in an unrepresentative average. No trend is observed between total $\mathrm{N}$ and elevation (Fig. 4c). Total $\mathrm{N}$ would not be a good method to distinguish between Quil Streams and Groundwater since they are not statistically different (t-test: $10 p<0.072$.

Snow and ice melt provide limited quantities of nitrogen, mostly as $\mathrm{NO}_{3}^{-}$and $\mathrm{NH}_{4}^{+}$ (Tranter, 2005) and it is possible that $\mathrm{NH}_{4}^{+}$is sourced from mica and feldspar dissolution (Holloway et al., 1998) and some may originate from oxidation of organic matter. Cattle, horses and sheep which graze in the valley could also contribute to measured total $\mathrm{N}$.

The average $\mathrm{Si}$ for all samples was measured to be $9.5 \mathrm{ppm} \mathrm{Si}$ as $\mathrm{SiO}_{2}$ with a range of $0.5-1.3 \mathrm{ppm} \mathrm{Si}$ as $\mathrm{SiO}_{2}$. The Quil Streams group had an average value of $9.3 \mathrm{ppm}$ $\mathrm{Si}$ as $\mathrm{SiO}_{2}$ and a range of 4.4-1.1 $\mathrm{ppm} \mathrm{Si}$ as $\mathrm{SiO}_{2}$. Tributaries had an average value of $9.0 \mathrm{ppm} \mathrm{Si}$ as $\mathrm{SiO}_{2}$ and $4.1-11 \mathrm{ppm} \mathrm{Si}$ as $\mathrm{SiO}_{2}$. Groundwater samples had an average value of $11.9 \mathrm{ppm} \mathrm{Si}$ as $\mathrm{SiO}_{2}$ and a range of $9.9-13.5 \mathrm{ppm} \mathrm{Si}$ as $\mathrm{SiO}_{2}$. The samples

20 J Spring (\#12) and Quil Spring (\#23) have the highest Si concentrations of all the samples from Quilcayhuanca while Cay Spring (\#15) is close to the overall average. Silica could potentially be used to distinguish between groundwater and surface water samples since Groundwater values are significantly different (t-test: $p<0.024)$ from Quil Streams. Si concentrations increase down valley for Quil Streams (Fig. 4d). However, 25 this trend is not quite statistically significant at the $5 \%$ significance level.

Silica in most low-temperature natural waters is derived from silicate weathering (Hounslow, 1995). In proglacial environments, carbonate dissolution and sulfide oxidation reactions dominate initially after glacier retreat, but these minerals become exhausted as silicate weathering increases. Colonization of the proglacial zone by 2497

plants further increases the rate of chemical weathering of silicates (Anderson et al., 2000). These observations coincide well with the measured concentrations of $\mathrm{Si}$ and how they vary with elevation in this study. Presumably the oldest glacial deposits are in the lower portions of the valley and these deposits have been interacting with naturally 5 acidic waters for quite some time. As a result, carbonate and sulfide minerals in these lower, older sediment portions of the valley have probably been exhausted leading to increased silicate weathering in these areas.

\subsection{Isotopes}

The stable isotopes $\delta^{18} \mathrm{O}$ and $\delta^{2} \mathrm{H}$ were measured and deuterium excess was cal10 culated for the samples from Quilcayhuanca basin (Table 6). The average $\delta^{18} \mathrm{O}$ for the entire valley was $-16.7 \%$ with a range of -17.8 to $-14.4 \%$. For Quil Streams the average was $-16.9 \%$ with a range of -17.8 to $-16.3 \%$. Tributaries had an average value of $-16.6 \%$ with a range of -17.6 to $-14.4 \%$. Groundwater samples had an average value of $-16.0 \%$ with a range of -17.5 to $-15.3 \%$. J Spring (\#12) and

15 Quil Spring (\#23) have identical values while Cay Spring (\#15) is low (depleted). One possible explanation is that Cay Spring has a shorter residence time or flow path than the other two springs indicating that the sample has undergone less evaporation than the other groundwater. As a result, the surface water that initially entered this spring has undergone less fractionation than the other two sites. This theory is supported

20 by measurements of conductivity. Cay Spring has the lowest conductivity of the three groundwater sites. With a longer residence time, the quantity of mass dissolved in groundwater increases (Schwartz, 2003) and thus so does conductivity.

A plot of $\delta^{18} \mathrm{O}$ versus elevation shows an elevation effect of $-0.155 \%$ per $100 \mathrm{~m}$ of elevation rise (Fig. 6a). This elevation effect is approximately two times as large as the 25 elevation effect observed for the nonglacierized Cordillera Negra $(-0.07 \%$ per $100 \mathrm{~m})$ by Mark et al. (2007) from 2004-2006. Although it is difficult to quantify the amount of glacier meltwater in the surface waters of Quilcayhuanca, this comparison shows that meltwater is a significant component during the dry season. 
The average $\delta^{2} \mathrm{H}$ for the entire valley was $-126 \%$ with a range of -134 to $-110 \%$. For Quil Streams the average was $-126 \%$ o with a range of -134 to $-120 \%$. Tributaries had an average value of $-126 \%$ with a range of -134 to $-110 \%$. Groundwater samples had an average of $-122 \%$ with a range of -134 to $-115 \%$. A plot of $\delta^{18} \mathrm{O}$ versus $5 \delta^{2} \mathrm{H}$ shows a potential local meteoric water line for Quilcayhuanca valley, assuming that stream samples can act as a proxy for precipitation (Fig. 6b; McKenzie et al., 2001). The local meteoric water line falls below the global meteoric water line (MWL), similar to observations by Mark et al. (2007).

\subsection{Mixing model}

10 The two-component mixing model was used to calculate that the Quil Bel Conf (\#19) site is comprised of $76 \%$ surface water and $24 \%$ groundwater with a standard deviation of $\pm 16 \%$ (Table 8 ). The Park Entrance site (\#24) is estimated to be $66 \%$ surface water and $34 \%$ groundwater with a standard deviation of $\pm 12 \%$. These two sites are not statistically different (t-test: $p<0.27$ ) in terms of their relative contribution from

15 surface water and groundwater. In general, however, it appears that groundwater is a slightly larger component at the lower site after the streams cross the potential pampa groundwater storage sites.

A similar, but more complex, model was applied to the $7 \%$ glacierized Querococha basin of the Cordillera Blanca by Baraer et al. (2009) where groundwater is the dom20 inant contributor to Querococha surface waters during the dry season. The authors noted that the relative contribution from groundwater is variable, ranging from 18 to $74 \%$, but that proglacial groundwater contributions are a key component of the dry season hydrologic system in this valley and likely the rest of the Cordillera Blanca. Our results confirm the importance of groundwater in proglacial environments, and indicate

25 that it should be accounted for when quantifying water resources, particularly during the dry season (Baraer et al., 2009).

\subsection{Upscaling to the Rio Santa}

Of interest is how the results from this study can be extrapolated to the larger Cordillera Blanca watershed. Interestingly, groundwater sites from Quilcayhuanca resemble the Rio Santa more closely than Quilcayhuanca surface waters. Furthermore, the aver-

5 age composition of groundwater, the Rio Santa, and the Cordillera Negra all fall on a mixing line. Assuming Quilcayhuanca water is representative of broader groundwater compositions, groundwater contributes approximately $60 \%$ to the Rio Santa and surface waters from the Cordillera Negra contributing approximately $40 \%$. Although groundwater sites from Quilcayhuanca fall on a mixing line with the Rio Santa and the

10 Cordillera Negra, groundwater from Quilcayhuanca alone obviously does not contribute $60 \%$ of the dry season discharge to the Rio Santa but is representative of groundwater chemical compositions.

The Cordillera Blanca itself might contribute $60 \%$ of dry season discharge to the Rio Santa, similar to what Mark et al. (2005) observed, if groundwater in other valleys is 15 similar in ionic composition to the groundwater in Quilcayhuanca or if groundwater in Quilcayhuanca is similar to surface waters and groundwater in the other valleys. The ionic composition of groundwater in Quilcayhuanca measured in this study is very similar to the average ionic composition of the major tributaries to the Rio Santa measured by Mark et al. (2005) whose authors estimated that the Cordillera Blanca contributes 20 about $66 \%$ of dry season discharge while the Cordillera Negra contributes about $33 \%$.

The average $\delta^{18} \mathrm{O}$ and $\delta^{2} \mathrm{H}$ of Quilcayhuanca, the Rio Santa, and the Cordillera Negra were plotted with horizontal and vertical bars representing one standard deviation to represent mixing of these groups (Fig. 7). The waters from Quilcayhuanca have the most negative values of $\delta^{18} \mathrm{O}$ and $\delta^{2} \mathrm{H}$ resulting from glacier melt and runoff derived

25 from higher elevation precipitation. Based on average isotopic values of the Rio Santa and Cordillera Negra (Table 7) and the assumption that the site Quilcay (\#25; $2 \mathrm{~km}$ from the Rio Santa) is representative of the Cordillera Blanca, this mixing model suggests that between $27 \%\left(\delta^{18} \mathrm{O}\right)$ and $38 \%\left(\delta^{2} \mathrm{H}\right)$ of the water in the Rio Santa is derived 
from the Cordillera Blanca. This calculation is a crude estimate of relative contributions to the Rio Santa since discharge and precipitation are not included and one valley is used to represent the entire Cordillera Blanca. Nevertheless, it is a useful exercise and provides the foundation for further more detailed studies.

5 Isotopically, it is of interest that the groundwater $\delta^{18} \mathrm{O}$ values are statistically different (t-test: $p<0.037$ ) from surface waters samples and on average have more positive values. Normally $\delta{ }^{18} \mathrm{O}$ of shallow groundwater and $\delta^{18} \mathrm{O}$ of local precipitation are approximately the same (Clark and Fritz, 1997). However, in the Cordillera Blanca most precipitation falls in the wet season and is usually more depleted than the most nega-

10 tive value measured in Quilcayhuanca in this study. Thus shallow groundwater, at least in Quilcayhuanca, is not a mirror image of wet season precipitation and therefore dry season precipitation should not be a major factor in determining the isotopic composition of groundwater since precipitation during this time is usually at a minimum.

\section{Conclusions}

15 Rivers draining the Cordillera Blanca provide water for downstream communities, and during the dry-season water resources are particularly stressed with ongoing climate change (Bury et al., 2010). Water resources are defined by the volume of available water and the water's quality for a given activity. The water discharging from the Quilcayhuanca basin is not potable for domestic use due to the low $\mathrm{pH}$ and high dissolved

$20 \mathrm{SO}_{4}$ and metal load (Fortner et al., 2011). With ongoing glacier retreat, additional fresh rock faces of the Chicama Formation will be exposed up-valley, leading to sustained, if not worsening, water quality.

The results of the study show how the chemistry of melt-water changes downstream from glaciers in the Cordillera Blanca, and that not only the importance of groundwa-

25 ter in maintaining dry season discharge, but that groundwater is generally isotopically distinct from that glacier meltwater. The key findings from this research are:

1. Pyrite oxidation is the dominant mineral weathering reaction in the proglacial zone of Quilcayhuanca. This reaction adds protons to solution and lowers the $\mathrm{pH}$ to below 4 at many sites. As a result of such a low $\mathrm{pH}$ there is almost no alkalinity and igneous rocks are readily weathered, resulting in high solute concentrations. $5 \quad$ The sampling group Quil Streams is characterized by $\mathrm{Ca}^{2+}, \mathrm{Mg}^{2+}$, and $\mathrm{SO}_{4}^{2-}$ which are consistent with the mapped lithology of granodiorite/tonalite and the metasedimentary Chicama formation.

2. Hydrochemical parameters show trends with elevation and distance from the glaciers. $\mathrm{pH}$ decreases with elevation but specific conductance increases. Both of these trends support the influx of groundwater in lower portions of the valley. Total P and total $\mathrm{N}$ of the Quil Streams sites show no trend with elevation. Si concentrations increase with decreasing elevation because sulfide and carbonate minerals have been more exhausted at lower elevations. An elevation effect of $-0.155 \%$ per $100 \mathrm{~m}$ rise in elevation was observed for $\delta^{18} \mathrm{O}$ which is nearly twice the published elevation effect of the nonglacierized Cordillera Negra. This signifies that glacier melt is a large reason why Quilcayhuanca $\delta^{18} \mathrm{O}$ stream values are much more negative than would normally be expected for the given elevation range.

3. Surface water and groundwater in Quilcayhuanca are geochemically different. $\mathrm{pH}$ is lower for surface waters as a result of increased interaction with abundant pyrite. Specific conductance is lower for groundwater samples due to their near neutral $\mathrm{pH}$ and decreased dissolution potential. Groundwater in this basin had considerably higher relative percentages of $\mathrm{Na}^{+}$and $\mathrm{K}^{+}$as a result of cation exchange processes and dissolution of trace carbonates. Surface waters had considerably higher relative percentages of $\mathrm{Mg}^{2+}, \mathrm{Fe}^{2+}, \mathrm{H}^{+}$, and $\mathrm{SO}_{4}^{2-}$ relative to groundwater. Groundwater usually has almost no total $\mathrm{P}$ and higher concentrations of $\mathrm{Si}$, relative to surface waters. $\delta^{18} \mathrm{O}$ and $\delta^{2} \mathrm{H}$ of groundwater are, on average, more positive than $\delta^{18} \mathrm{O}$ and $\delta^{2} \mathrm{H}$ of surface waters. These differences provide ways to 
differentiate between groundwater and surface water. These differentiations aid in the selection of parameters for mixing models.

4. Using a simple, two end-member mixing model, the surface waters leaving the valley at the lowest site in the drainage basin were calculated to be a mixture of approximately two-thirds surface water (mostly glacier melt) and one-third groundwater. Pampas could potentially increase the relative contribution from groundwater in the lower valley. While groundwater likely contributes the most water to dry season Rio Santa discharge, this study confirms the findings of Baraer et al. (2009) that there is significant dry season variation in the role of groundwater in individual basins of the Cordillera Blanca.

Acknowledgements. We are very grateful to a number of colleagues for their help and guidance with this project. Berry Lyons and Sue Welch were very helpful with all questions related to geochemistry. Kyung-In Huh and Jeff La Frenierre assisted with analysis of geospatial data. Anne Carey provided a very thorough and helpful review. We would also like to thank all those

5 who were part of our team during the summer 2009 field season for helping to collect so many water samples and other crucial hydrological data.

Funding for this research was provided by a grant from Climate, Water, and Carbon (CWC) program at The Ohio State University as well as an Arts and Sciences Undergraduate Research Scholarship.

\section{References}

Anderson, S., Drever, J., and Humphrey, N.: Chemical Weathering in Glacial Environments, Geology, 25, 399-402, 1997.

Anderson, S., Drever, J., Frost, C., and Holden, P.: Chemical Weathering in the Foreland of a Retreating Glacier, Geochim. Cosmochim. Ac., 64, 1173-189, 2000.

25 Anderson, S., Longacre, S., and Kraal, E.: Patterns of Water Chemistry and Discharge in the Glacier-fed Kennicott River, Alaska: Evidence for Subglacial Water Storage Cycles, Chem. Geol., 202, 297-312, 2003.

Armstrong, R., Raup, B., Khalsa, S. J. S., Barry, R., Kargel, J., Helm, C., and Kieffer, H.: GLIMS glacier database. Boulder, Colorado USA: National Snow and Ice Data Center, Digital media, 2005.

Baraer, M., McKenzie, J. M., Mark, B. G., Bury, J., and Knox, S.: Characterizing contributions of glacier melt and groundwater during the dry season in a poorly gauged catchment of the Cordillera Blanca (Peru), Adv. Geosci., 22, 41-49, doi:10.5194/adgeo-22-41-2009, 2009.

Bair, S. and Lahm, T.: Practical Problems in Groundwater Hydrology, Pearson Prentice Hall, New Jersey, 2006.

Barnett, T., Adam, J., and Lettenmaier, D.: Potential Impacts of a Warming Climate on Water Availability in Snow-dominated Regions, Nature, 438, 303-309, 2005.

Bradley, R., Vuille, M., Diaz, H., and Vergara, W.: Threats to Water Supplies in the Tropical Andes, Science, 312, 1755-1756, 2006.

Brown, G.: Glacier Meltwater Hydrochemistry, Appl. Geochem., 17, 855-883, 2002.

Bury, J., Mark, B., McKenzie, J., and French, A.: Glacier Recession and Human Vulnerability in 15 the Yanamarey Watershed of the Cordillera Blanca, Peru, Climatic Change, 105, 179-206, doi:10.1007/s10584-010-9870-1, 2010.

Clark, I. and Fritz, P.: Environmental Isotopes in Hydrogeology, CRC/Lewis, Boca Raton, FL, 1997.

Cooper, R., Wadham, J., Tranter, M., Hodgkins, R., and Peters, N.: Groundwater Hydrochemistry in the Active Layer of the Proglacial Zone, Finsterwalderbreen, Svalbard, J. Hydrol., 269, 208-223, 2002.

Faure, G.: Principles and Applications of Geochemistry, Prentice Hall, Upper Saddle River, N.J., 1998.

Fortner, S., Mark, B., McKenzie, J., Bury, J., and Baraer, M.: Elevated stream metal concentrations in the foreland of a tropical glacier, Appl. Geochem., in press, 2011.

Hodson, A.: Phosphorus in Glacial Meltwaters, in: Glacier Science and Environmental Change, edited by: Knight, P., Blackwell Pub., Malden, MA, 2009.

Hodson, A., Mumford, P., and Lister, D.: Suspended Sediment and Phosphorus in Proglacial Rivers: Bioavailability and Potential Impacts upon the P Status of Ice-marginal Receiving Waters, Hydrol. Process., 18, 2409-2422, 2004.

Holland, H. D.: The Chemistry of the Atmosphere and Oceans, Wiley, New York, 1978.

Holloway, J. M., Dahlgren, R. A., Hansen, B., and Casey, W. H.: Contribution of Bedrock Nitrogen to High Nitrate Concentrations in Streamwater, Nature, 395, 785-788, 1998. 
Hood, J. L., Roy, J. W., and Hayashi, M.: Importance of Groundwater in the Water Balance of an Alpine Headwater Lake, Geophys. Res. Lett., 33, L13405, doi:10.1029/2006GL026611, 2006.

Hounslow, A.: Water Quality Data: Analysis and Interpretation, Lewis, Boca Raton, 1995.

5 Mark, B. G. and McKenzie, J. M.: Tracing Increasing Tropical Andean Glacier Melt with Stable Isotopes in Water, Environ. Sci. Technol., 41, 6955-6960, 2007.

Mark, B. G. and Seltzer, G. O.: Tropical Glacier Meltwater Contribution to Stream Discharge: a Case Study in the Cordillera Blanca, Peru, J. Glaciol., 49, 271-281, 2003.

Mark, B. G., McKenzie, J. M., and Gomez, J.: Hydrolochemical Evaluation of Changing Glacier Meltwater Contribution to Stream Discharge: Callejon De Huaylas, Peru, Hydrolog. Sci. J., 50, 975-987, 2005.

McKenzie, J. M., Siegel, D. I., Patterson, W., and McKenzie, D. J.: A Geochemical Survey of Spring Water from the Main Ethiopian Rift Valley, Southern Ethiopia: Implications for WellHead Protection, Hydrogeol. J., 9, 265-272, 2001.

15 McKenzie, J. M., Mark, B. G., Thompson, L. G., Schotterer, U., and Lin, P.-N.: A hydrogeochemical survey of Kilimanjaro (Tanzania) springs: implications for water sources and ages, Hydrogeol. J., 18, 985-995, doi:10.1007/s10040-009-0558-4, 2010.

McNulty, B. A., Farber, D. L., Wallace, G. S., Lopez, R., and Palacios, O.: Role of plate kinematics and plate-slip-vector partitioning in continental magmatic arcs: Evidence from the Cordillera Blanca, Peru, Geology, 26, 827-830, 1998.

Messerli, B.: The International Year of the Mountains, the Mountain Research Initiative, and PAGES editorial, Past Global Changes News, 9, p. 2, 2001.

O’Neill, P.: Environmental Chemistry, G. Allen \& Unwin, London, 1985.

Pouyaud, B.: Impact of climate change on water resources: the Rio Santa Basin (White Cordillera - Peru), CONAM, Bonn, Germany, 2004.

Pouyaud, B., Zapata, M., Yerren, J., Gomez, J., Rosas, G., Suarez, W., and Ribstein, P.: On the future of the water resources from glacier melting in the Cordillera Blanca, Peru, Hydrolog. Sci. J., 50, 999-1022, 2005.

Racoviteanu, A. E., Arnaud, Y., Williams, M. W., and Ordonez, J.: Decadal Changes in Glacier Parameters in the Cordillera Blanca, Peru, Derived from Remote Sensing, J.f Glaciol., 54, 499-510, 2008.

Schwartz, F. W. and Zhang, H.: Fundamentals of Ground Water, Wiley, New York, 2003.

Tranter, M.: Geochemical Weathering in Glacial and Proglacial Environments, in: Surface and 2505

Ground Water, Weathering, and Soils, edited by: Drever, J. I., Elsevier, Amsterdam, 2005.

Vergara, W., Deeb, A., Valencia, A., Bradley, R., Francou, B., Zarzar, A., Grunwaldt, A., and Haeussling, S.: Economic impacts of rapid glacial retreat in the Andes, Eos, Transactions American Geophysical Union, 88, 261-263, 2007.

5 Vuille, M., Francou, B., Wagnon, P., Juen, I., Kaser, G., Mark, B. G., and Bradley, R. S.: Climate Change and Tropical Andean Glaciers: Past, Present and Future, Earth-Sci. Rev., 89, 79-96, 2008.

Weingartner, R., Viviroli, D., and Schadler, B.: Water resources in mountain regions: a methodological approach to assess the water balance in a highland-lowland system, Hydrol. Process., 21, 578-585, 2007. 
Table 1. Quilcayhuanca Field Measurements by Group.

\begin{tabular}{|c|c|c|c|c|c|}
\hline Site Name & Group/Subgroup & Site \# & $\begin{array}{c}\text { Elevation } \\
\text { ma.s.I. }\end{array}$ & $\mathrm{pH}$ & $\begin{array}{r}\text { Conductivity } \\
\mu \mathrm{S} \mathrm{cm}^{-1}\end{array}$ \\
\hline Cuchillacocha out & Quil-R & 1 & 4624 & 3.4 & 478 \\
\hline Tulpacocha & Quil-R & 4 & 4290 & $3.4^{*}$ & - \\
\hline Lower Lake (Tupla) Out & Quil-R & 5 & 4282 & 3.4 & 495 \\
\hline Jatun & Quil-R & 10 & 4178 & 3.5 & 390 \\
\hline Cuchi Conf & Quil-R & 13 & 4148 & 3.8 & 304 \\
\hline Tulp Low & Quil-R & 14 & 4148 & 3.8 & 281 \\
\hline V2 Ab Pacsa & Quil-R & 16 & 4056 & 3.9 & 258 \\
\hline Tulp Ab Conf & Quil-R & 17 & 4034 & 4.1 & 259 \\
\hline Quil-R Avg. & & & 4220 & 3.6 & 352 \\
\hline Cay Hi & Quil-L & 7 & 4232 & 3.8 & 226 \\
\hline Cay Ab Conf & Quil-L & 18 & 4032 & 4.6 & 391 \\
\hline Quil-L Avg. & & & 4132 & 4.1 & 309 \\
\hline Quil Bel Conf & Quil-M & 19 & 4031 & 4.3 & 296 \\
\hline Casa de Agua & Quil-M & 22 & 3917 & 3.7 & 293 \\
\hline Park Entrance & Quil-M & 24 & 3835 & 4.1 & 228 \\
\hline Quilcay & Quil-M & 25 & 3109 & 5.4 & 241 \\
\hline Quil-M Avg. & & & 3723 & 4.1 & 265 \\
\hline Quil Streams Avg. & & & & 3.8 & 318 \\
\hline Jatun Upper Conf & Tribs & 2 & 4564 & 6.3 & 176 \\
\hline Jatun Mid & Tribs & 3 & 4292 & 6.4 & 133 \\
\hline Cay L1 & Tribs & 6 & 4236 & 3.2 & 421 \\
\hline Cay Red & Tribs & 8 & 4216 & 3.0 & 314 \\
\hline Cay L2 & Tribs & 9 & 4180 & 4.5 & 242 \\
\hline Cay L3 & Tribs & 11 & 4177 & 2.8 & 130 \\
\hline South Waterfall & Tribs & 20 & 3995 & 3.8 & 179 \\
\hline North Waterfall & Tribs & 21 & 3994 & 7.1 & 53 \\
\hline Tributaries Avg. & & & 4207 & 3.4 & 206 \\
\hline J Spring & GW & 12 & 4162 & 6.8 & 88 \\
\hline Cay Spg & GW & 15 & 4109 & 6.1 & 26 \\
\hline Quil Spring & GW & 23 & 3878 & 7.3 & 116 \\
\hline Avg. Groundwater & & & 4050 & 6.4 & 77 \\
\hline
\end{tabular}

* July 2008 measurement; - indicates no measurement

Table 2. Quilcayhuanca Ion Concentrations by Group.

\begin{tabular}{|c|c|c|c|c|c|c|c|c|c|c|c|c|c|}
\hline \multirow[t]{2}{*}{ Site Name } & \multirow[t]{2}{*}{ Subgroup } & \multirow{2}{*}{$\begin{array}{l}\text { Site } \\
\text { Number }\end{array}$} & Elevation & $\mathrm{Ca}^{2+}$ & $\mathrm{Mg}^{2+}$ & $\mathrm{Na}^{+}$ & $\mathrm{K}^{+}$ & $\mathrm{Fe}^{2+}$ & $\mathrm{H}^{+}$ & $\mathrm{F}^{-}$ & $\mathrm{Cl}^{-}$ & $\mathrm{HCO}_{3}^{-}$ & $\mathrm{SO}_{4}^{2-}$ \\
\hline & & & ma.s.l. & \multicolumn{10}{|c|}{ meq $\mathrm{I}^{-1}$} \\
\hline $\begin{array}{l}\text { Cuchillacocha out } \\
\text { Tulpacocha }\end{array}$ & $\begin{array}{l}\text { Quil-R } \\
\text { Quil-R }\end{array}$ & $\begin{array}{l}2 \\
5\end{array}$ & $\begin{array}{l}4624 \\
4290\end{array}$ & 1.59 & 1.12 & 0.06 & 0.02 & 0.16 & 0.42 & 0.01 & 0.01 & 0.00 & 3.15 \\
\hline $\begin{array}{l}\text { Lower Lake (lupla) Uut } \\
\text { Jatun }\end{array}$ & Quil-R & 12 & 4178 & $\begin{array}{l}1.45 \\
1.39\end{array}$ & 0.83 & 0.07 & 0.02 & 0.06 & 0.33 & 0.01 & 0.01 & 0.00 & 2.70 \\
\hline Cuchi Conf & Quil-R & 15 & 4148 & 1.11 & 0.66 & 0.09 & 0.02 & 0.04 & 0.16 & 0.01 & 0.01 & 0.00 & 2.23 \\
\hline Tulpa Low & Quil-R & 16 & 4148 & 0.65 & 0.57 & 0.04 & 0.02 & 0.03 & 0.17 & 0.01 & 0.01 & 0.00 & 2.04 \\
\hline V2 Ab Pacsa & Quil-R & 19 & 4056 & 0.77 & 0.55 & 0.06 & 0.02 & 0.02 & 0.13 & 0.01 & 0.01 & 0.00 & 2.00 \\
\hline Tulp Ab Conf & Quil-R & 20 & 4034 & 0.77 & 0.56 & 0.06 & 0.02 & 0.02 & 0.09 & 0.01 & 0.02 & 0.00 & 2.01 \\
\hline Quil-R Avg. & & & 4220 & 1.11 & 0.77 & 0.07 & 0.02 & 0.06 & 0.25 & 0.01 & 0.01 & 0.00 & 2.46 \\
\hline Cay Hi & Quil-L & 9 & 4232 & 0.78 & 0.38 & 0.03 & 0.01 & 0.02 & 0.15 & 0.00 & 0.01 & 0.00 & 1.44 \\
\hline Cay Ab Conf & Quil-L & 21 & 4032 & 1.24 & 0.78 & 0.04 & 0.01 & 0.35 & 0.02 & 0.01 & 0.01 & 0.00 & 2.85 \\
\hline Quil-L Avg. & & & 4132 & 1.01 & 0.58 & 0.03 & 0.01 & 0.18 & 0.09 & 0.01 & 0.01 & 0.00 & 2.15 \\
\hline Quil Bel Conf & Quil-M & 22 & 4031 & 0.88 & 0.58 & 0.06 & 0.02 & 0.09 & 0.05 & 0.01 & 0.01 & 0.00 & 2.18 \\
\hline Casa de Agua & Quil-M & 26 & 3917 & 0.85 & 0.58 & 0.06 & 0.02 & 0.07 & 0.19 & 0.01 & 0.02 & 0.00 & 2.14 \\
\hline Park Entrance & Quil-M & 28 & 3835 & 0.68 & 0.50 & 0.09 & 0.02 & 0.02 & 0.08 & 0.01 & 0.02 & 0.00 & 1.85 \\
\hline Quilcay & Quil-M & 29 & 3109 & 0.94 & 0.37 & 0.10 & 0.03 & 0.00 & 0.00 & 0.00 & 0.06 & 0.00 & 1.48 \\
\hline Quil-M Avg. & & & 3723 & 0.84 & 0.51 & 0.08 & 0.02 & 0.04 & 0.08 & 0.01 & 0.03 & 0.00 & 1.91 \\
\hline Quil Main Streams Avg. & & & 4065 & 1.01 & 0.66 & 0.06 & 0.02 & 0.07 & 0.17 & 0.01 & 0.02 & 0.00 & 2.24 \\
\hline Jatun Upper Conf & Tribs & 3 & 4564 & 1.24 & 0.30 & 0.07 & 0.02 & 0.00 & 0.00 & 0.01 & 0.01 & 0.12 & 1.48 \\
\hline Jatun Mid & Tribs & 4 & 4292 & 0.68 & 0.22 & 0.09 & 0.03 & 0.00 & 0.00 & 0.01 & 0.01 & 0.00 & 1.09 \\
\hline Cay L1 & Tribs & 8 & 4236 & 0.48 & 0.49 & 0.01 & 0.00 & 0.05 & 0.62 & 0.01 & 0.01 & 0.00 & 2.04 \\
\hline Cay Red & Tribs & 10 & 4216 & 4.09 & 2.47 & 0.12 & 0.02 & 1.07 & 1.00 & 0.04 & 0.00 & 0.00 & 11.69 \\
\hline Cay L2 & Tribs & 11 & 4180 & 0.57 & 0.46 & 0.02 & 0.01 & 0.00 & 0.03 & 0.01 & 0.01 & 0.00 & 1.71 \\
\hline Cay L3 & Tribs & 13 & 4177 & 0.82 & 1.15 & 0.07 & 0.01 & 0.61 & 1.58 & 0.05 & 0.01 & 0.00 & 5.19 \\
\hline South Waterfall & Tribs & 24 & 3995 & 0.38 & 0.26 & 0.05 & 0.01 & 0.01 & 0.17 & 0.01 & 0.01 & 0.00 & 1.20 \\
\hline North Waterfall & Tribs & 25 & 3994 & 0.34 & 0.03 & 0.05 & 0.02 & 0.00 & 0.00 & 0.01 & 0.01 & 0.23 & 0.19 \\
\hline Tributaries Avg. & & & 4207 & 1.07 & 0.67 & 0.06 & 0.01 & 0.22 & 0.43 & 0.02 & 0.01 & 0.04 & 3.07 \\
\hline J Spring & GW & 14 & 4162 & 0.29 & 0.10 & 0.15 & 0.03 & 0.00 & 0.00 & 0.00 & 0.01 & 0.22 & 0.34 \\
\hline Cay & GW & 17 & 4109 & 0.14 & 0.02 & 0.05 & 0.01 & 0.00 & 0.00 & 0.01 & 0.00 & 0.08 & 0.13 \\
\hline Quil Spring & GW & 27 & 3878 & 0.35 & 0.17 & 0.16 & 0.05 & 0.09 & 0.00 & 0.01 & 0.01 & 0.12 & 0.67 \\
\hline Groundwater Avg. & & & 4050 & 0.26 & 0.10 & 0.12 & 0.03 & 0.03 & 0.00 & 0.01 & 0.01 & 0.14 & 0.38 \\
\hline
\end{tabular}


Table 3. Rio Santa and Cordillera Negra Ion Concentrations.

\begin{tabular}{|c|c|c|c|c|c|c|c|c|c|c|c|c|}
\hline \multirow[t]{2}{*}{ Site Name } & \multirow[t]{2}{*}{ Subgroup } & \multirow{2}{*}{$\begin{array}{c}\text { Elevation } \\
\text { ma.s.I. }\end{array}$} & $\mathrm{Ca}^{2+}$ & $\mathrm{Mg}^{2+}$ & $\mathrm{Na}^{+}$ & $\mathrm{K}^{+}$ & $\mathrm{Fe}^{2+}$ & $\mathrm{H}^{+}$ & $\mathrm{F}^{-}$ & $\mathrm{Cl}^{-}$ & $\mathrm{HCO}_{3}^{-}$ & $\mathrm{SO}_{4}^{2-}$ \\
\hline & & & \multicolumn{10}{|c|}{ meq $^{-1}$} \\
\hline Jangas & Santa & 2807 & & & & & & & & & & \\
\hline Santa 1 & Santa & 3800 & 1.43 & 0.26 & 0.52 & 0.06 & 0.01 & - & 0.00 & 0.32 & 1.62 & 0.33 \\
\hline Santa 2 & Santa & 3462 & 1.07 & 0.45 & 0.67 & 0.08 & 0.00 & - & 0.01 & 0.29 & 0.67 & 1.30 \\
\hline Santa Low & Santa & 2000 & 2.18 & 0.57 & 0.71 & 0.09 & 0.00 & - & 0.01 & 0.56 & 1.39 & 1.59 \\
\hline Conococha & Santa & 4020 & 0.56 & 0.13 & 0.36 & 0.06 & 0.01 & - & 0.00 & 0.02 & 0.00 & 2.05 \\
\hline Santa Tica & Santa & 3433 & 0.95 & 0.28 & 0.29 & 0.05 & 0.01 & - & 0.00 & 0.01 & 1.54 & 0.03 \\
\hline La Recreta & Santa & 3990 & 1.49 & 0.24 & 0.42 & 0.05 & 0.01 & - & 0.00 & 0.00 & 1.60 & 0.59 \\
\hline Pteucushacu & Santa & 3930 & 1.36 & 0.22 & 0.44 & 0.05 & 0.00 & - & 0.00 & 0.03 & 0.48 & 1.57 \\
\hline Santa Catac & Santa & 3547 & 1.25 & 0.37 & 0.38 & 0.06 & 0.00 & - & 0.00 & 0.22 & 1.07 & 0.77 \\
\hline Rio Santa Avg. & & 3443 & 1.29 & 0.31 & 0.47 & 0.06 & 0.00 & & 0.00 & 0.18 & 1.05 & 1.03 \\
\hline Negra 1 & Negra & 4004 & 0.16 & 0.09 & 0.08 & 0.02 & 0.00 & - & 0.00 & 0.23 & 0.00 & 0.57 \\
\hline Negra 2 & Negra & 3973 & 2.32 & 0.61 & 0.41 & 0.03 & 0.00 & - & 0.01 & 0.02 & 1.96 & 1.39 \\
\hline Negra Anta & Negra & 2765 & 2.16 & 1.23 & 0.66 & 0.07 & 0.00 & - & 0.01 & 0.10 & 3.42 & 0.58 \\
\hline Negra Low & Negra & 2038 & 2.02 & 0.32 & 1.26 & 0.04 & 0.00 & - & 0.00 & 0.01 & 3.49 & 0.13 \\
\hline Cord. Negra Avg. & & 3195 & 1.66 & 0.56 & 0.60 & 0.04 & 0.00 & & 0.01 & 0.09 & 2.22 & 0.67 \\
\hline
\end{tabular}

- indicates no measurement

2509

Table 4. Nutrient Concentrations for Quilcayhuanca by Group.

\begin{tabular}{|c|c|c|c|c|c|c|}
\hline Site Name & Subgroup & Site \# & $\begin{array}{c}\text { Elevation } \\
\text { ma.s.l. }\end{array}$ & $\begin{array}{r}\text { Total } \mathrm{P} \\
\mathrm{ppb} \mathrm{P} \text { as } \mathrm{PO}_{4}^{3-}\end{array}$ & $\begin{array}{r}\text { Total } \mathrm{N} \\
\mathrm{ppbN} \text { as } \mathrm{NO}_{3}^{-}\end{array}$ & ppb Si as $\mathrm{SiO}_{2}$ \\
\hline Cuchillacocha out & Quil-R & 2 & 4624 & 1343 & 389 & 7954 \\
\hline Tulpacocha & Quil-R & 5 & 4290 & 1291 & 202 & 8248 \\
\hline Lower Lake (Tupla) Out & Quil-R & 6 & 4282 & 1335 & 364 & 8919 \\
\hline Jatun & Quil-R & 12 & 4178 & 1376 & 401 & 9411 \\
\hline Cuchi Conf & Quil-R & 15 & 4148 & 1179 & 605 & 10810 \\
\hline Tulpa Low & Quil-R & 16 & 4148 & 1289 & 278 & 8990 \\
\hline V2 Ab Pacsa & Quil-R & 19 & 4056 & 1342 & 384 & 10382 \\
\hline Tulp Ab Conf & Quil-R & 20 & 4034 & 1307 & 369 & 10260 \\
\hline Quil-R Avg. & & & 4220 & 1308 & 374 & 9372 \\
\hline Cay Hi & Quil-L & 9 & 4232 & 687 & 161 & 4395 \\
\hline Cay Ab Conf & Quil-L & 21 & 4032 & 1352 & 364 & 8400 \\
\hline Quil-L Avg. & & & 4132 & 1020 & 263 & 6397 \\
\hline Quil Bel Conf & Quil-M & 22 & 4031 & 1337 & 274 & 10059 \\
\hline Casa de Agua & Quil-M & 26 & 3917 & 1297 & 345 & 9968 \\
\hline Park Entrance & Quil-M & 28 & 3835 & 1211 & 308 & 10505 \\
\hline Quilcay & Quil-M & 29 & 3109 & 692 & 708 & 10504 \\
\hline Quil-M Avg. & & & 3723 & 1134 & 409 & 10259 \\
\hline Quil Main Streams Avg. & & & 4065 & 1211 & 381 & 9274 \\
\hline Jatun Upper Conf & Tribs & 3 & 4564 & 30 & 232 & 9033 \\
\hline Jatun Mid & Tribs & 4 & 4292 & 22 & 256 & 10815 \\
\hline Cay L1 & Tribs & 8 & 4236 & 1273 & 336 & 4062 \\
\hline Cay Red & Tribs & 10 & 4216 & 2197 & 245 & 10990 \\
\hline Cay L2 & Tribs & 11 & 4180 & 1080 & 330 & 7988 \\
\hline Cay L3 & Tribs & 13 & 4177 & 1301 & 233 & 10814 \\
\hline South Waterfall & Tribs & 24 & 3995 & 0 & 234 & 10056 \\
\hline North Waterfall & Tribs & 25 & 3994 & 0 & 201 & 8574 \\
\hline Tributaries Avg. & & & 4207 & 738 & 258 & 9041 \\
\hline J Spring & GW & 14 & 4162 & 23 & 1957 & 12153 \\
\hline Cay Spg & GW & 17 & 4109 & 9 & 205 & 9965 \\
\hline Quil Spring & GW & 27 & 3878 & 1297 & 345 & 13541 \\
\hline Avg. Groundwater & & & 4050 & 443 & 836 & 11887 \\
\hline
\end{tabular}


Table 5. Nutrient Concentrations of the Rio Santa and Cordillera Negra.

\begin{tabular}{|c|c|c|c|c|c|}
\hline Site Name & Subgroup & $\begin{array}{c}\text { Elevation } \\
\text { ma.s.l. }\end{array}$ & $\begin{array}{r}\text { Total } \mathrm{P} \\
\mathrm{ppb} \mathrm{P} \text { as } \mathrm{PO}_{4}^{3-}\end{array}$ & $\begin{array}{r}\text { Total } \mathrm{N} \\
\text { ppb } \mathrm{N} \text { as } \mathrm{NO}_{3}^{-}\end{array}$ & ppb Si as $\mathrm{SiO}_{2}$ \\
\hline Jangas & Santa & 2807 & 943 & 1919 & 11460 \\
\hline Santa 1 & Santa & 3800 & 1164 & 488 & 10812 \\
\hline Santa 2 & Santa & 3462 & 1166 & 642 & 11207 \\
\hline Santa Low & Santa & 2000 & 1407 & 2127 & 12162 \\
\hline Conococha & Santa & 4020 & 78 & 909 & 484 \\
\hline Santa Tica & Santa & 3433 & 1155 & 544 & 10504 \\
\hline La Recreta & Santa & 3990 & - & - & - \\
\hline Pteucushacu & Santa & 3930 & 825 & 351 & 10992 \\
\hline Santa Catac & Santa & 3547 & 1195 & 347 & 9966 \\
\hline Rio Santa Avg. & & 3443 & 999 & 772 & 9447 \\
\hline Negra 1 & Negra & 4004 & 0 & 305 & 9796 \\
\hline Negra 2 & Negra & 3973 & 13 & 231 & 13541 \\
\hline Negra Anta & Negra & 2765 & 1210 & 1153 & 11758 \\
\hline Negra Low & Negra & 2038 & 643 & 815 & 13542 \\
\hline Cord. Negra Avg. & & 3195 & 467 & 626 & 12159 \\
\hline
\end{tabular}

- indicates no measurement

2511

Table 6. Stable Isotopes for Quilcayhuanca by Group.

\begin{tabular}{llrrrrr}
\hline Site Name & Subgroup & $\begin{array}{r}\text { Site \# } \\
\text { Cuchillacocha out }\end{array}$ & $\begin{array}{c}\text { Elevation } \\
\text { ma.s.I. }\end{array}$ & $\begin{array}{c}\delta^{18} \mathrm{O} \\
\%\end{array}$ & $\begin{array}{c}\delta^{2} \mathrm{H} \\
\%\end{array}$ & D-excess \\
\hline Tulpacocha & Quil-R & 2 & 4624 & -17.8 & -134 & 7.9 \\
Lower Lake (Tupla) Out & Quil-R & 5 & 4290 & -17.0 & -126 & 9.9 \\
Jatun & Quil-R & 6 & 4282 & -17.4 & -127 & 11.9 \\
Cuchi Conf & Quil-R & 12 & 4178 & -17.4 & -129 & 10.2 \\
Tulpa Low & Quil-R & 15 & 4148 & -17.0 & -129 & 7.1 \\
V2 Ab Pacsa & Quil-R & 16 & 4148 & -17.0 & -128 & 7.9 \\
Tulp Ab Conf & Quil-R & 19 & 4056 & -16.8 & -123 & 10.9 \\
\hline Quil-R Avg. & Quil-R & 20 & 4034 & -16.8 & -126 & 8.5 \\
\hline Cay Hi & & & 4220 & -17.1 & -128 & 9.3 \\
Cay Ab Conf & Quil-L & 9 & 4232 & -16.5 & -120 & 11.9 \\
\hline Quil-L Avg. & Quil-L & 21 & 4032 & -16.7 & -126 & 8.0 \\
\hline Quil Bel Conf & & & 4132 & -16.6 & -123 & 9.9 \\
Casa de Agua & Quil-M & 22 & 4031 & -16.9 & -126 & 8.8 \\
Park Entrance & Quil-M & 26 & 3917 & -16.6 & -126 & 6.7 \\
Quilcay & Quil-M & 28 & 3835 & -16.5 & -126 & 6.0 \\
\hline Quil-M Avg. & Quil-M & 29 & 3109 & -16.3 & -124 & 6.9 \\
\hline Quil Main Streams Avg. & & & 3723 & -16.6 & -126 & 7.1 \\
\hline Jatun Upper Conf & Tribs & 3 & 4564 & -17.6 & -132 & 8.7 \\
Jatun Mid & Tribs & 4 & 4292 & -16.6 & -127 & 5.8 \\
Cay L1 & Tribs & 8 & 4236 & -16.8 & -125 & 9.5 \\
Cay Red & Tribs & 10 & 4216 & -14.4 & -110 & 4.9 \\
Cay L2 & Tribs & 11 & 4180 & -16.8 & -125 & 9.5 \\
Cay L3 & Tribs & 13 & 4177 & -16.9 & -127 & 7.7 \\
South Waterfall & Tribs & 24 & 3995 & -17.8 & -134 & 8.4 \\
North Waterfall & Tribs & 25 & 3994 & -16.3 & -126 & 4.5 \\
\hline Tributaries Avg. & & & 4207 & -16.6 & -126 & 7.4 \\
\hline J Spring & GW & 14 & 4162 & -15.3 & -118 & 4.6 \\
Cay Spg & GW & 17 & 4109 & -17.5 & -134 & 5.7 \\
Quil Spring & GW & 27 & 3878 & -15.3 & -115 & 7.7 \\
\hline Avg. Groundwater & & & 4050 & -16.0 & -122 & 6.0 \\
\hline & & & & & & \\
\hline
\end{tabular}


Table 7. Stable Isotope Results for the Rio Santa and Cordillera Negra.

\begin{tabular}{|c|c|c|c|c|c|c|}
\hline Site Name & Subgroup & Site \# & $\begin{array}{c}\text { Elevation } \\
\text { ma.s.I. }\end{array}$ & $\begin{array}{c}\delta^{18} \mathrm{O} \\
\% \circ\end{array}$ & $\begin{array}{l}\delta^{2} \mathrm{H} \\
\% \circ\end{array}$ & D-excess \\
\hline Jangas & Santa & & 2807 & -15.1 & -118 & 3.0 \\
\hline Santa 1 & Santa & & 3800 & -12.6 & -105 & -4.1 \\
\hline Santa 2 & Santa & & 3462 & -14.9 & -112 & 7.1 \\
\hline Santa Low & Santa & & 2000 & -14.8 & -114 & 5.0 \\
\hline Conococha & Santa & & 4020 & -10.4 & -96 & -12.8 \\
\hline Santa Tica & Santa & & 3433 & -14.7 & -115 & 2.7 \\
\hline La Recreta & Santa & & 3990 & -16.2 & -125 & 4.5 \\
\hline Pteucushacu & Santa & & 3930 & -13.1 & -108 & -2.7 \\
\hline Santa Catac & Santa & & 3547 & -14.6 & -113 & 3.6 \\
\hline Rio Santa Avg. & & & 3443 & -13.9 & -111 & 0.4 \\
\hline Negra 1 & Negra & & 4004 & -13.8 & -110 & 0.3 \\
\hline Negra 2 & Negra & & 3973 & -13.7 & -115 & -6.0 \\
\hline Negra Anta & Negra & & 2765 & -12.1 & -96 & 1.1 \\
\hline Negra Low & Negra & & 2038 & -12.3 & -92 & 6.1 \\
\hline Cord. Negra Avg & & & 3195 & -13.0 & -103 & 0.4 \\
\hline
\end{tabular}

Table 8. Results of Mixing Model with Overall Averages and Standard Deviations for $f_{1}$ and $f_{2}$.

\begin{tabular}{|c|c|c|c|c|c|c|c|c|c|}
\hline \multirow[t]{5}{*}{ Quil Bel Conf } & & $\begin{array}{l}\text { Conduc. } \\
\mu \mathrm{S} \mathrm{cm}^{-1}\end{array}$ & $\begin{array}{c}\mathrm{Ca}^{2+} \\
\mathrm{meql}^{-1}\end{array}$ & $\begin{array}{c}\mathrm{Mg}^{2+} \\
\text { meql }^{-1}\end{array}$ & $\begin{array}{c}\mathrm{SO}_{4}^{2-} \\
\mathrm{meql}^{-1}\end{array}$ & ppb Si as $\mathrm{SiO}_{2}$ & $\begin{array}{l}\delta^{18} \mathrm{O} \\
\% \circ\end{array}$ & & \\
\hline & $C_{\mathrm{qms}}$ & 342 & 1.09 & 0.73 & 2.39 & 8777 & -17.0 & & \\
\hline & $C_{\mathrm{gw}}$ & 57 & 0.21 & 0.06 & 0.24 & 11059 & -16.4 & & \\
\hline & $C_{\text {out }}^{\text {gin }}$ & 296 & 0.88 & 0.58 & 2.18 & 10059 & -16.9 & & \\
\hline & & & & & & & & Average & 1 Stdev \\
\hline \multirow{2}{*}{$\begin{array}{l}\text { Surface Water } \\
\text { Groundwater }\end{array}$} & $f_{1}$ & 0.84 & 0.76 & 0.78 & 0.90 & 0.44 & 0.83 & 0.76 & 0.16 \\
\hline & $f_{2}$ & 0.16 & 0.24 & 0.22 & 0.10 & 0.56 & 0.17 & 0.24 & \\
\hline \multirow[t]{6}{*}{ Park Entrance } & & Conduc. & $\mathrm{Ca}^{2+}$ & $\mathrm{Mg}^{2+}$ & $\mathrm{SO}_{4}^{2-}$ & $\mathrm{Si}$ & $\delta^{18} \mathrm{O}$ & & \\
\hline & & $\mu \mathrm{Scm}^{-1}$ & meq $^{-1}$ & meql $^{-1}$ & meql $^{-1}$ & ppb Si as $\mathrm{SiO}_{2}$ & $\%$ & & \\
\hline & $C_{\mathrm{qms}}$ & 300 & 0.94 & 0.61 & 2.18 & 9186 & -16.8 & & \\
\hline & $\mathrm{G}_{\mathrm{gw}}$ & 77 & 0.26 & 0.10 & 0.38 & 11887 & -16.04 & & \\
\hline & $C_{\text {out }}^{\text {sw }}$ & 228 & 0.68 & 0.50 & 1.85 & 10505 & -16.5 & & \\
\hline & & & & & & & & Average & 1 Stdev \\
\hline \multirow{2}{*}{$\begin{array}{l}\text { Surface Water } \\
\text { Groundwater }\end{array}$} & $f_{1}$ & 0.68 & 0.63 & 0.78 & 0.82 & 0.51 & 0.55 & 0.66 & 0.12 \\
\hline & $f_{2}$ & 0.32 & 0.37 & 0.22 & 0.18 & 0.49 & 0.45 & 0.34 & \\
\hline
\end{tabular}




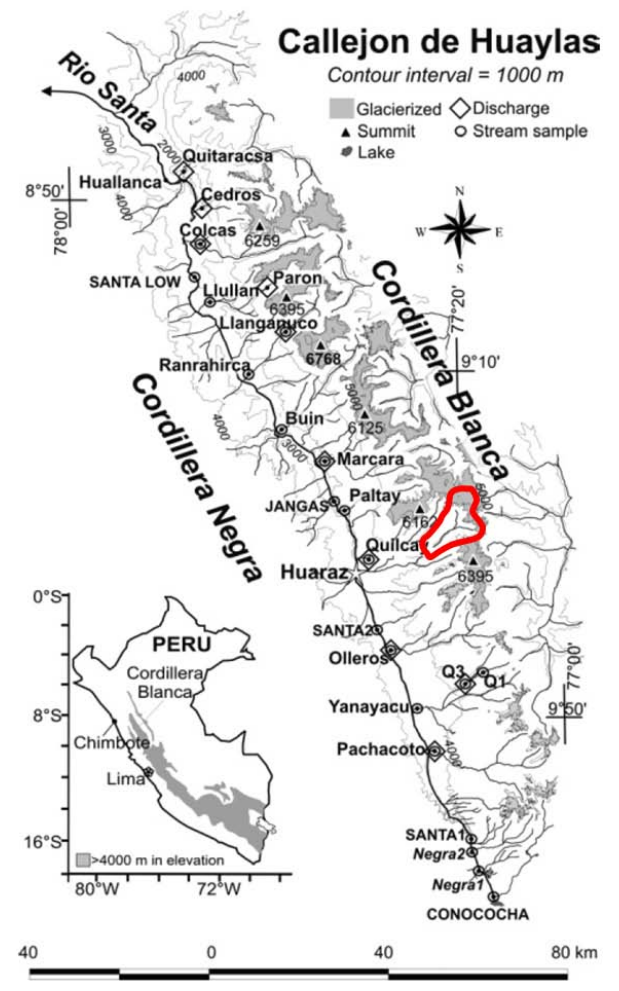

Fig. 1. Map of study site. Map of the Cordillera Blanca (modified from Mark and McKenzie, 2007). The red outline shows the approximate location of the Quilcayhuanca drainage basin relative to the Cordillera Blanca and the Rio Santa.
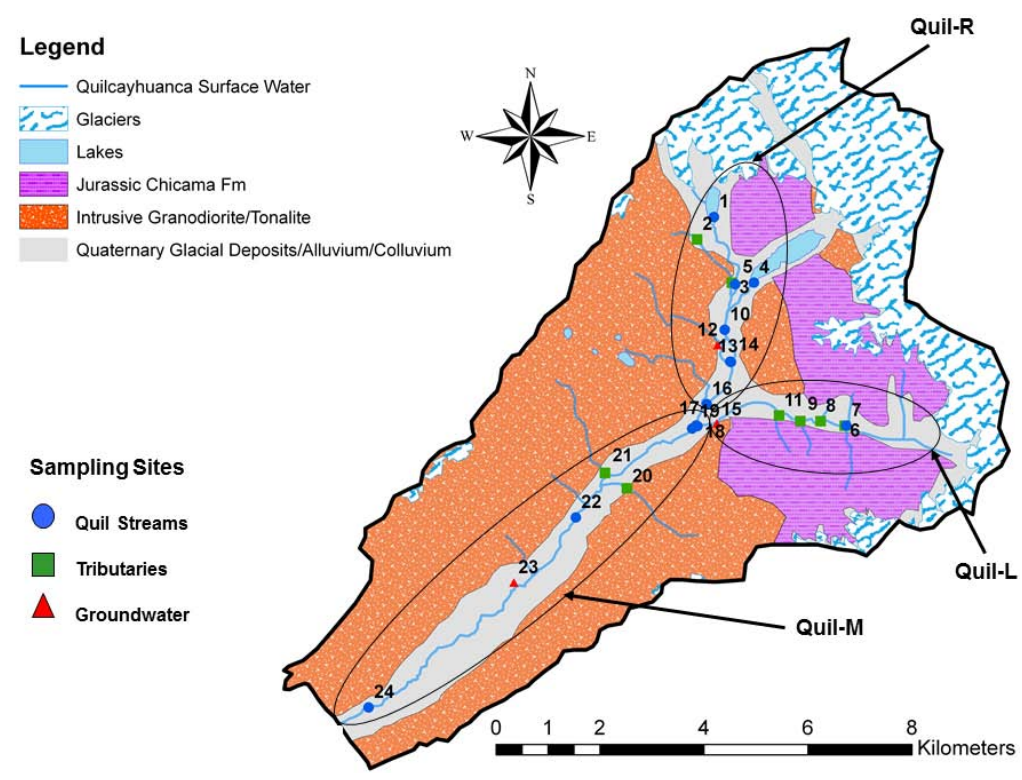

Fig. 2. Geologic Map of Quilcayhuanca drainage basin with sampling site locations. This geologic map shows the major formations of the Quilcayhuanca drainage basin, including glaciers and lakes. Sampling locations are plotted with symbols appropriate to their grouping. Labeled ovals surround the three sections of the valley: Quil-L, Quil-R, and Quil-M. 


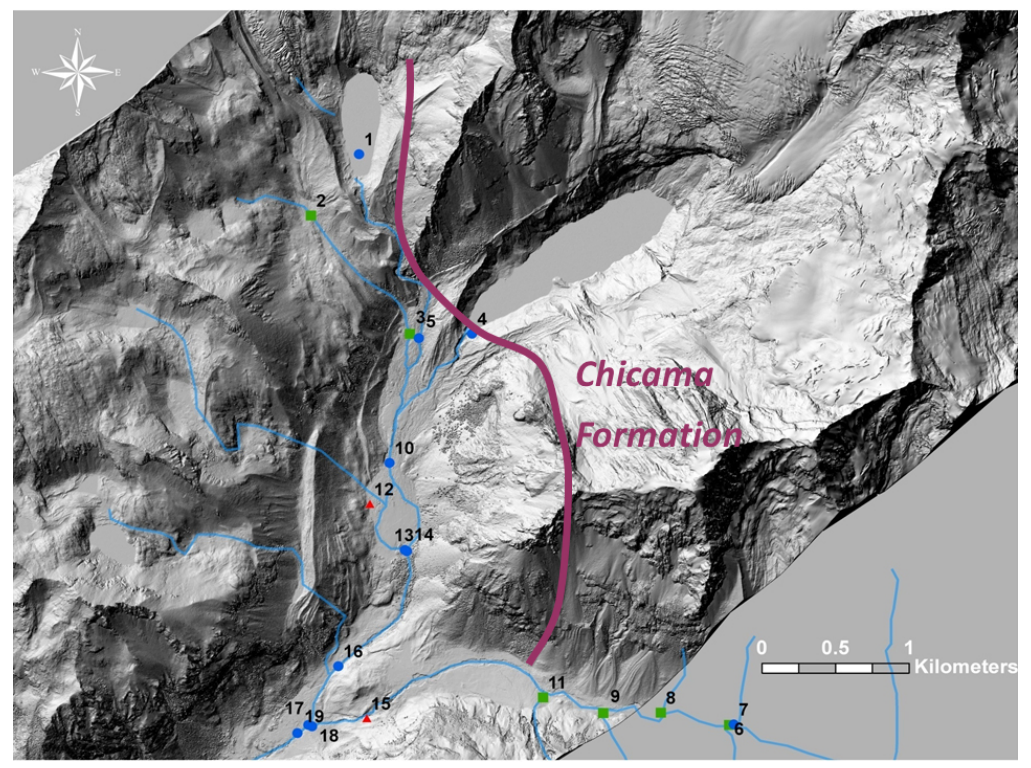

Fig. 3. LiDAR hillshade of the Upper Portion of Quilcayhuanca Valley with Sampling Sites and Chicama contact. The LiDAR hillshade focuses on the upper part of Quilcayhuanca valley. Sampling locations are plotted with symbols appropriate to their grouping. The Chicama formation contact (thick purple line) was interpreted from the geologic map. Solid light-grey areas are zones where LiDAR data was not acquired.

(a)

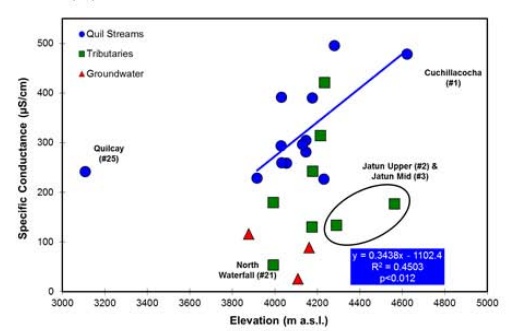

(c)

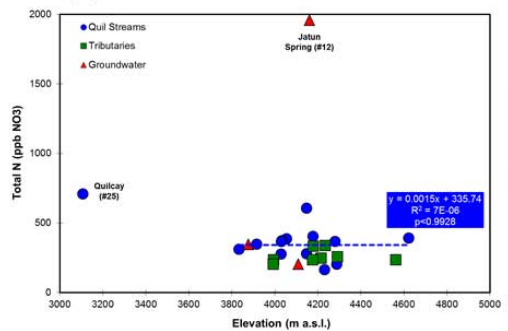

(b)

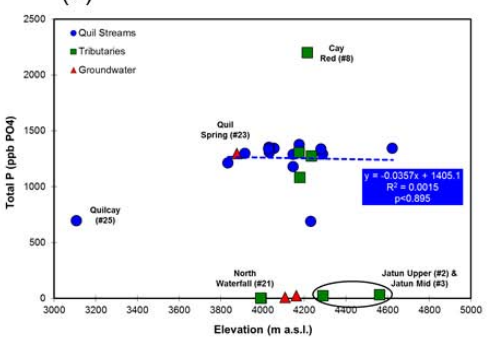

(d)

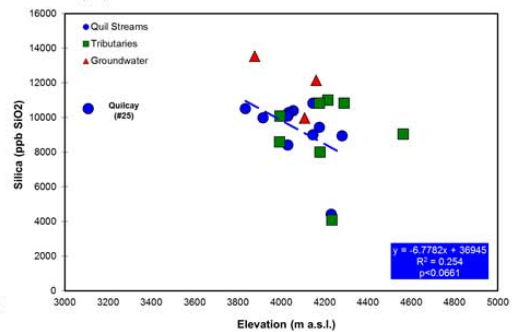

Fig. 4. Plots of specific conductance and nutrients versus elevation. (a) Specific Conductance. Cuchillacocha Lake in Quil-R has the highest specific conductance while samples with a higher pH (groundwater samples and sites \#2, \#3, and \#21) have the lowest specific conductance. A trend line fit only through Quil Streams, but excluding Quilcay (\#25) because it is outside of the drainage basin, shows that specific conductance decreases with decreasing elevation. The solid blue line indicates that the trend is significant at the $5 \%$ significance level. (b) Total $\mathrm{P}$ versus Elevation. No trend is observed between total $\mathrm{P}$ and elevation for the group Quil Streams. The blue, dotted line indicates that the trend line for Quil Streams is not significant at the $5 \%$ level of significance. (c) Total $\mathrm{N}$ versus Elevation. No trend was observed between total $\mathrm{N}$ and elevation and there is no distinction between groundwater and surface water sites. The blue, dotted line indicates that the trend line for Quil Streams is not significant at the $5 \%$ level of significance. (d) $\mathrm{Si}$ versus Elevation. Si increases with decreasing elevation for Quil Streams. The site Quilcay (\#25) is excluded from this trend line because it is outside of the drainage basin. The blue, dashed line indicates that this trend line is not quite statistically significant at the $5 \%$ significance level. 


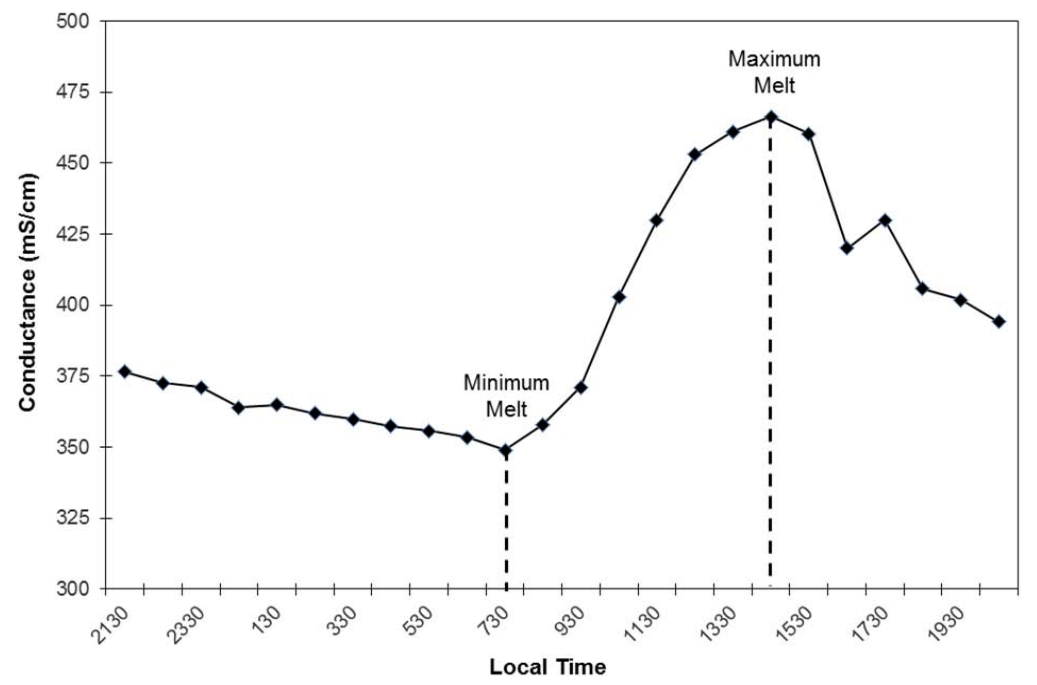

Fig. 5. Specific conductance versus Local Time $(24 \mathrm{~h})$ at the Quil Bel Conf site. Specific conductance is theorized to correlate with glacier meltwater contribution. The maximum specific conductance value corresponds to peak glacial meltwater contribution (14:30) while the lowest specific conductance value corresponds to a minimum meltwater contribution (07:30).

(a)

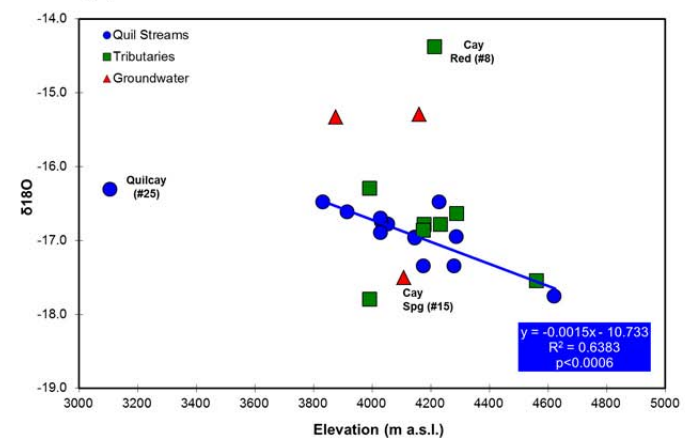

(b)

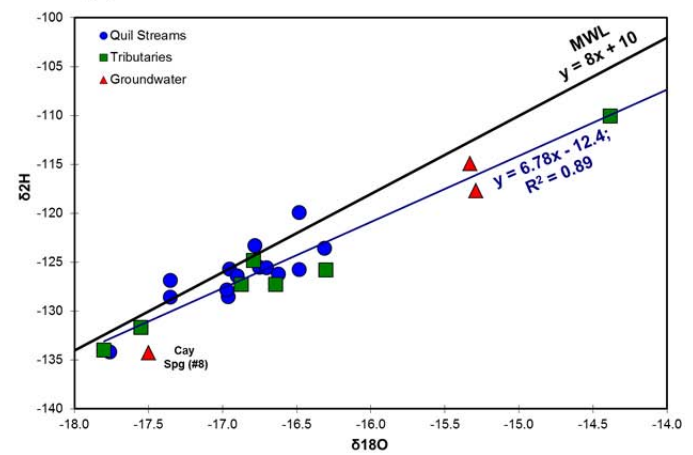

Fig. 6. (a) $\delta^{18} \mathrm{O}$ versus elevation. In general, groundwater sites have more positive $\delta^{18} \mathrm{O}$. For the group Quil Streams, excluding Quilcay (\#25) because it is outside of the drainage basin, $\delta^{18} \mathrm{O}$ decreases with increasing elevation at a rate of $-0.155 \%$ per $100 \mathrm{~m}$ rise. The solid blue line indicates that this trend is significant at the $5 \%$ significance level. (b) $\delta^{18} \mathrm{O}$ versus $\delta^{2} \mathrm{H}$. The dark blue line is fit through all Quilcayhuanca samples and represents a proxy for a meteoric derived local meteoric water line. 


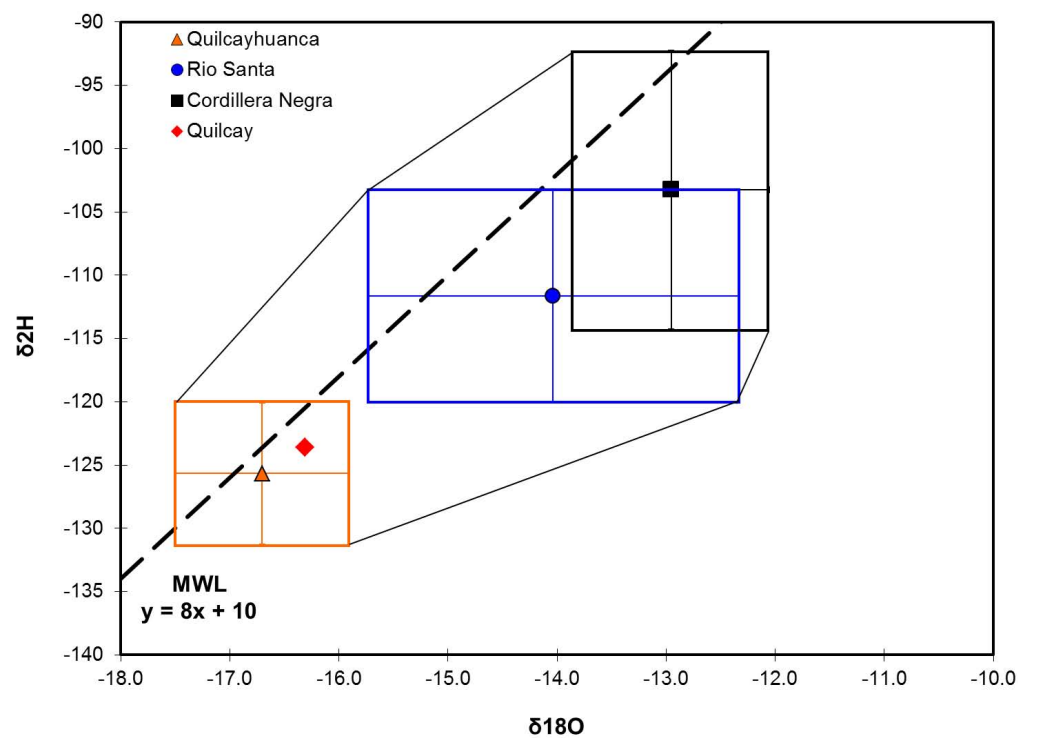

Fig. 7. Average $\delta^{18} \mathrm{O}$ versus average $\delta^{2} \mathrm{H}$ for Quilcayhuanca, Rio Santa, and Cord. Negra Average $\delta^{18} \mathrm{O}$ and $\delta^{2} \mathrm{H}$ for Quilcayhuanca, the Rio Santa, and the Cordillera Negra are plotted with 1 standard deviation. The Rio Santa is a mixture of the more negative isotopic values from Quilcayhuanca and the more positive values from the nonglacierized Cordillera Negra. 